\title{
Evaluation of Deposit Insurance Fund Adequacy Using Credit Risk Model—An Indian Experience
}

\author{
Steward Doss \\ National Insurance Academy, Pune, India
}

\begin{abstract}
There are two methods widely used for evaluating the adequacy of Deposit Insurance Fund: (i) Target Reserve Ratio and (ii) Credit Risk Model. Target Reserve Ratio is one of the macro level indicators more often set by Regulatory act on the basis of minimum Deposit Insurance Fund margin safety. Target Reserve Ratio is calculated as the ratio of Deposit Insurance Fund to the value of insured deposits. However, TRR does not take into consideration the level of Deposit Insurance potential liability, the Loss at Given Default (LGD) and the historical trend of default rate prevailing among the insured banks. It does not also consider the present condition of the economy and current scenario of the banking sector. This paper discusses primarily about development of Credit Risk Model for evaluating the Deposit Insurance Fund Adequacy. For this purpose, Econometric Credit Risk Model was developed based on the historical data of bank failures and the associated losses of the last 25 years from 1990-91 to 2014-15. The model assesses various possible factors impacting the Deposit Insurance Fund: Default rate, Deposit growth, Exposures, impact of macro-economic factors like GDP, GDS, Inflation and Interest rate changes, etc. on the Deposit Insurance Fund through econometric modeling. The model evaluates the adequacy of Deposit Insurance Fund under both (i) Normal scenarios where there is no (economic) systemic risk assumed and (ii) Worst case scenario at $1 \%$ level of significance using Monte Carlo Simulation. Since the model empirically validates all the critical factors impacting the assets and liabilities associated with Loss at Given Default, the model output can also be used to determine a suitable Target Reserve Ratio and such models are being used in countries like USA, Canada, Hong Kong, and Singapore, etc. (IADI, 2009). More importantly, the model outputs are quite useful in determining the adequacy of deposit insurance fund which is an effective risk control measure that organization like Deposit Insurance Credit Guarantee Corporation (DICGC) can adopt both under normal economic scenario as well as worst case scenario, ensuring a strong financial safety net for the banking sector in India. The model also assesses the default probability and the Loss at Given Default of different types of banks: commercial banks, rural banks, cooperative banks, foreign banks, etc. A risk based on premium can possibly be determined for each type of banks in India.
\end{abstract}

Keywords: default probability, Loss at Given Default, Target Reserve Ratio, assessable deposits, cash reserve ratio, capital to risk weighted asset ratio

Steward Doss, Dr., associate professor, National Insurance Academy, Pune, India.

Correspondence concerning this article should be addressed to Steward Doss, 25, National Insurance Academy, Baner, Pune 411045, India. 


\section{Introduction and Need for the Study}

Deposit Insurance plays a key role in maintenance of financial stability by sustaining public confidence in the banking system through protection of depositors, especially small and less sophisticated depositors, against loss of deposit. The need for deposit insurance arose from frequent instances of bank failures that adversely impacted depositor confidence. Over time, financial stability and protection of small depositors have emerged as the primary reasons for spread of deposit insurance across the world (IADI, 2011).

Deposit Insurance and Credit Guarantee Corporation (DICGC), which was established in 1962 with funding from the Reserve Bank of India, is the body that operates the deposit insurance system in India. All commercial banks including the branches of foreign banks functioning in India, Local-Area Banks (LAB) and Regional Rural Banks (RRB) are covered under the Deposit Insurance scheme. Similarly, all state, central, and primary co-operative banks functioning in the states/union territories are also covered under the scheme.

More than $80 \%$ of Deposit Insurance Systems in the world are ex-ante system where the size of Deposit Insurance Fund should be adequate not only to meet the liabilities arising out of failure of banks, but it must also be able to withstand unexpected losses if arises through systemic risks triggered by economic recession/banking sector failures to some extent (IADI, 2009). In such conditions, eventually maintaining sufficiently a large Deposit Insurance Fund becomes very essential not only to instill confidence in the minds of deposit holders but also to ensure the financial stability for the banking sector. Currently the Indian economy is greatly impacted by the Global recession as the GDP growth has dropped down to 7\% for the years from 2012 to 2014 while inflation still continues to rise steeply (see Table 1 enclosed in the Appendix 1). Moreover, the approval of Retail Bill allowing Foreign Direct Investment in retail sector and the increase of Foreign Equity staking up to 49\% in the insurance sector would further augment the money supply and inflation which may also rise significantly in the country. It would increase the exposure of Deposit Insurance Fund in terms of increased insured deposits, while, this may also result in decrease of the lending rate for the banks that might reduce their earnings to a large extend. More importantly, the present financial market has become highly volatile now with greater interest rate fluctuation across different class of investment assets (call money, CBLO, bank deposits, government securities, and equity etc.). Thus, such unpredictable market conditions along with higher interest rate volatility, and also the increasing cost of operation of deposit insurance strongly necessitate the importance of estimating the adequacy of Deposit Insurance Fund (Beat \& Susanna, 2009).

Realizing the above importance and need, the present paper discusses the following:

(1) Evaluation of the Deposit Insurance Fund Adequacy using Econometric Credit Risk Model developed based on the historical data of last 25 years from 1990-91 to 2014-15.

(2) Analyze the historical trend of key factors constituting the fund i.e. Premiums collected, Deposit growth, Default rate and the loss exposures at given default rate/claims payouts, recoveries, investment income, and administrative expenses, etc. with a view to projecting these factors for next two years (2015 to 2016), using Monte Carlo Simulations.

(3) To evaluate the adequacy of Deposit Insurance Fund using Credit Risk Modeling under both (i) Normal scenarios where there is no (economic) systemic risk assumed and (ii) Worst case scenario at $1 \%$ level of significance using Monte Carlo Simulation.

\section{Methods for Evaluating Deposit Insurance Fund Adequacy}


There are two methods available for evaluating Deposit Insurance Fund adequacy.

(1) Target Reserve Ratio (TRR) and,

(2) Credit Risk Modeling.

\section{Target Reserve Ratio (TRR)}

Target Reserve Ratio is one of the macro level indicators more often set by Regulatory act on the basis of minimum Deposit Insurance Fund margin safety. Target Reserve Ratio is calculated as the ratio of Deposit Insurance Fund to the value of insured deposits. However, TRR does not take into consideration the level of Deposit Insurance potential liability, the Loss at Given Default (LGD) and the historical trend of default rate prevailing among the insured banks. It does not also consider the present condition of the economy and current scenario of the banking sector. Hence, most of the institutions in Asia Pacific Region ${ }^{1}$, particularly, Taiwan and Indonesia have a TRR of 2\% to 2.5\%, while Russia, Azerbaijan, and Kazakhstan use relatively higher TRR up to 5\% (IADI, 2011).

\section{Credit Risk Modeling}

Other method which has been widely used by the Deposit Insurers in developed countries (such as USA, Canada, Japan etc.) is Credit Risk Modeling where the adequacy of Deposit Insurance Fund is determined based on the estimation of Probability of Default among the insured banks using the historical data and estimation of Loss at Given Default (LGD), the exposure at default. Impact of certain essential risk factors on Deposit Insurance Fund liability is also taken into consideration such as composition of insured banks (number, size, lines of business), deposit growth and quality of assets and liabilities of the insured banks, credit spreads, and loan defaults etc. (Rosalind, 2001; Sergey, Alexander, Roman, R. Alexey, Vladimir, \& G. Alexey, 2005). More importantly, it considers various macro-economic factors like GDP, GDS, inflation, interest rate movement etc. impacting the performance of financial sector including banking sector.

Further, the deposit insurers and the insured banks may be exposed to a wide variety of factors that are difficult to estimate in advance. Moreover, the activities of the deposit insurer itself may impact the claims liability and the adequacy of Deposit Insurance fund: Delayed estimate of claims liability, decreasing number of insured banks, high ante selection, low premium rates, inadequate reserving, decreasing investment income, etc. Even the regulatory changes of the supervisory authority such as liberal supervisory norm can increase the probability of bank failures, similarly, uniform flat rate or fixed rate premium (currently the premium charged by the DICGC is 10 paisa per Rs. 100 of deposits) across all categories of banks irrespective of the risk profile of the insured banks, can also have a significant impact on the Deposit Insurance Fund.

\section{Use of Credit Risk Model for Estimating the Deposit Fund Liability}

Since the Deposit Insurance System is created to maintain public confidence of the deposit holders and ensure the stability of the financial system, the size of Deposit Insurance Fund should be large enough to assure the depositors that it is sufficient to meet the potential losses and make the required claim payouts arising out of the insured deposits. Hence, the target size of the Deposit Insurance Fund should be estimated keeping in mind all the important parameters impacting the fund i.e. premium income, initial capital, investment income, recovery, possible claim payouts, tax liabilities, and operating expenses etc.

In the present study, an attempt has been made to use the Credit Risk Modeling for estimating the adequacy

\footnotetext{
${ }^{1}$ IADI, 2011. APRC Funding Research Paper.
} 
of Deposit Insurance Fund for DICGC by considering most of the above-discussed factors, subject to the availability of data.

Advantage of Credit Risk Model is that it uses the historical data of bank failures and the associated losses. More importantly various possible factors impacting the Deposit Insurance Fund: Default rate, Deposit growth, Exposures, impact of macro-economic factors like GDP, GDS, Inflation and Interest rate changes, etc. can also be studied on the Deposit Insurance Fund through econometric modeling as well as Monte Carlo Simulations. Further, Credit Risk Modeling is a more analytical method to determine a suitable Target Reserve Ratio and such models are being used in countries like USA, Canada, Hong Kong, and Singapore, etc. (Diane Ellis, FDIC, 2013).

\section{Analysis \& Findings of the Study}

\section{Development of the Credit Risk Model}

In the first step, historical trend analysis of the following variables has been made using the historical data collected for the last 25 years from the year 1991 to 2015:

- Default rate,

- Exposures (insured deposits),

- Growth of assessable deposits,

- Premium growth,

- Claim payouts,

- Recoveries,

- Investment income, etc.

In the next step, a series of econometric models for each of the above parameters were developed. These parameters were independently modeled using historical data of last 25 years (1990-91 to 2014-15) which have resulted into the following outputs for the year 2016:

- Estimation of default probability for various categories of banks (commercial banks/RRBs/Co-operative Banks),

- Growth of accessible deposits and insured deposits,

- Estimation of Loss at Given Default (LGD) and exposures,

- Estimation of premium income,

- Estimation of recoveries,

- Estimation of investment income and,

- Estimation of operational expenses.

Brief detail about the models used for estimating the parameters are given in the following paragraphs:

Estimation of default probability for different categories of banks. For this purpose, initially the banks were grouped into various categories, viz., Commercial Banks, PSU Banks, Private Sector Banks, Foreign Banks, Regional Rural Banks (RRB), and Co-operative Banks. Among these categories of banks, only two categories viz., Commercial Banks, and Co-operative Banks have defaulted in the past. Almost, all the Regional Rural Banks are basically subsidiaries of the large PSU Commercial Banks and, there has been no default in this category of banks in recent years; no supervisory data relating to this category of banks were also available. Hence the default probability has been estimated only for Commercial and Cooperative Banks.

The most challenging aspects of determining deposit insurance fund liability are: 
- Estimation of default probability rate among the insured banks and,

- Calculating the Loss at Given Default.

Some of the most commonly used approaches for this purpose are:

(1) Historical trend analysis of default rates using credit risk modeling;

(2) Market analysis using the Credit Ratings Agency (A. M. Best, S\&P, Moody etc.) based on the quality of assets and liabilities, credit spread, exposures of the insured banks;

(3) Use of supervisory ratings of the insured banks.

Reference to international practices on this subject strongly suggests the use of both credit risk models based on historical default rates (Daniel, 2004) and the supervisor ratings for estimating the default rate of the insured banks. Most of the developed countries like USA, Canada, Singapore, Hong Kong, etc. use both the methods (IADI, 2009). Hence, methodology of the present study focuses on the combined use of Credit Risk Modeling based on historical defaults of the insured banks and the supervisory ratings of the insured banks.

It has been observed that there are generally two popular criteria used in calculating the default risk of the insured banks: capital adequacy and supervisory ratings. For the commercial banks, we tried to collect the latest information available from the Reserve Bank of India-supervisory ratings. However, due to security reasons, the latest data of supervisory ratings were not available for the current financial year (2014-15). Hence, the earlier available supervisory ratings and capital adequacy data in various department of RBI were used as base year and subsequent progression of these banks from one level to another has been projected using moving average method. These data were used only for validating the output of our Credit Risk Model to comprehend the reliability of the results.

Urban Co-operative Banks (UCBs) in India have wide variations in their size of operation and coverage as they are generally confined to limited areas and sectors of operation. UCBs are classified into four grades, viz., Grade I, II, III, and IV. These grades are determined on the basis of the information collated from: (i) statutory returns and/or other statements received from banks; and (ii) statutory inspections/scrutiny of books of accounts of UCBs. The methodology for the classification uses the supervisory grading of the UCBs based on four basic indicators of financial soundness i.e. Solvency (based on net worth and $\mathrm{CRAR}^{2}$ ); Liquidity (related to compliance with $\mathrm{CRR}^{3} / \mathrm{SLR}^{4}$ ); Asset Quality (based on net NPA ${ }^{5}$ ); and Profitability.

Default probability for commercial banks. Majority of the commercial banks in India have very strong financial performance and capital adequacy. As it can be seen from a recent study of supervisory ratings of the Commercial Banks given in Table 1, commercial banks have supervisory ratings of A \& B (which are considered as "Good") but we cannot still rule out the possibility of default in commercial banks, particularly when the financial market is highly volatile.

The above analysis of supervisory ratings of the Commercial Banks indicates that nearly 18 out of a sample of 156 banks are in the high risk group having supervisory rating of D and a CRAR of below 9\%. This indicates that nearly $10 \%$ of the banks out of the total sample of banks, for whom supervisory inspection is carried out, are at financially critical level. It has been perceived that if these banks do not take further precaution and the Indian regulator also does not take adequate prudential steps, then, at least $1 \%$ of these banks may slip into insolvency.

\footnotetext{
2 Capital to risk-weighted assets ratio.

${ }^{3}$ Cash Reserve Ratio.

4 Statutory Lending Rate.

5 Non-Performing Assets.
} 
Table 1

Supervisory Ratings and CRAR for Commercial Banks

\begin{tabular}{llllll}
\hline CRAR/CAMELS & A & B & C & D & Total \\
\hline Above 12\% & 8 & 10 & 12 & 14 & 44 \\
9-12\% & 10 & 12 & 14 & 16 & 52 \\
Less than 9\% & 12 & 14 & 16 & 18 & 60 \\
Total & 30 & 36 & 42 & 48 & 156 \\
\hline
\end{tabular}

Note. Various literatures and statistics from RBI.

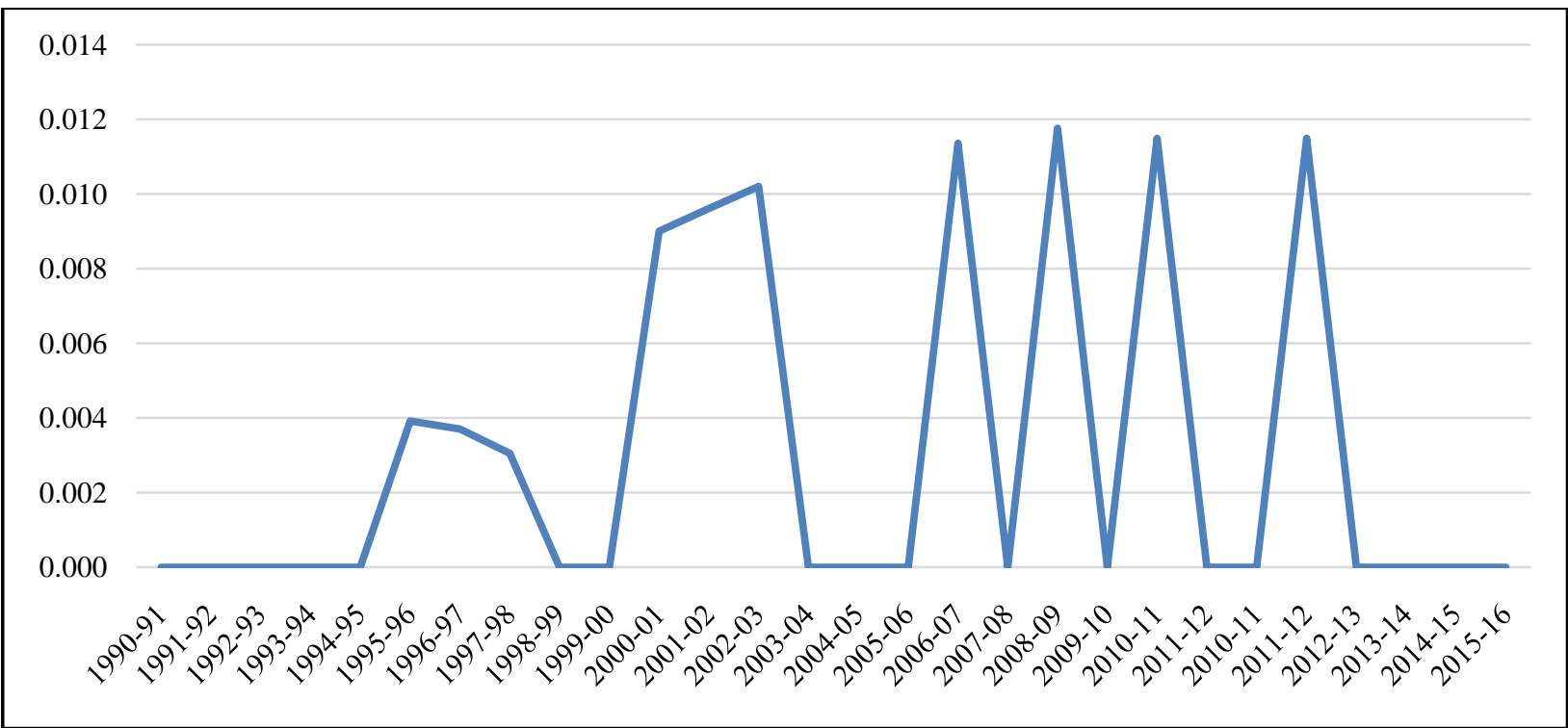

Figure 1. Probability of default for commercial banks.

Figure 1 exihibites the ratio of number of commercial banks which had defaulted to the total number of insured commercial banks from the historical period of 1994 to 2012. The historical analysis of de-registration of Commercial Banks which has attracted the liability indicates a probability of $1 \%$ (based on historical average of last 10 years' data). The confidential interval of the default probability indicates a default probability range of $0.60 \%$ to $1.4 \%$.

Exponential increase of assessable deposits of the Commercial Banks in recent years enhances its base exposures to a significantly higher level (insurance deposits amount to Rs. 21,360 billion for the year 2014-2015). 1\% default rate probability in commercial banks may trigger a potential loss of nearly Rs. 213 billion. This suggests that the risks in commercial banks should not be ignored while estimating the adequacy of Deposit Insurance Fund.

There is also need for estimating unexpected loss using Value at Risk (VaR) measures for protecting the Deposit Insurance Fund in case of a systemic risk occurrence in the near future (Sergey et al., 2005).

Though, strong prudential norms and higher supervisory control by the Reserve Bank of India may not allow the Commercial Banks to default — coupled with the fact that the large asset base and good support in terms of financial net protection from the banking system minimize the failure of Commercial Banks.

However, steadily increasing exposure of the large banks along with rising volatility of financial market increases the risk exposure for the Commercial Banks. Further, the lower growth of GDP with higher rate of 
inflation can create a greater risk exposure on the financial system as well as on the Deposit Insurance Funds (see Table 2 enclosed in Appendix 1). All these factors demand a higher Fund level to protect Deposit Insurance Fund from depletion in case of a systemic risk occurrence.

Default probability for co-operative banks. Co-operative banks cater mainly to the large number of small and marginal rural deposit holders. There has been a rapid growth of co-operative banks in the recent years (there are nearly 1,977 co-operative banks for the year 2014-15), and substantial exposures of insured deposits (insured deposits of Rs. 3,222 billion during the year 2014-15 as against Rs. 956 billion in 2002).

This strongly indicates that any failure or severe financial crisis in co-operative sector today suddenly imbalance the Deposit Insurance Fund. Secondly, the higher interest rates charged by co-operative banks coupled with increasing growth of deposits and higher rate of loan defaults make this sector highly vulnerable for default risk. Further concentration of its business in certain territories with large exposures increases accumulation risk also.

More importantly, non-differential premium (flat premium rate across all categories of banks) coupled with compulsory nature of Deposit Premium has created a strong adverse selection in co-operative banks as they contribute to larger claim payouts with marginally smaller premium. Secondly, the premium rates were not increased for the last eight years. Further, co-operative banks produce higher claims liability (Rs. 3,213 million in 2014-15) but the recoveries that are being collected from them are quite low which strongly indicates higher risk exposures from co-operative banks.

Apart from historical data of de-registration of insured banks, the supervisory ratings obtained from Department of Banking Supervision were used for assessing the default rate in co-operative banks.

As in case of commercial banks, the supervisory ratings for co-operative banks broadly comprise of the following parameters:

(1) Solvency measure-Net worth and CRAR;

(2) Liquidity related measures (CRR/SLR);

(3) Asset quality (Net NPA) and;

(4) Profitability.

On the basis of these measures, the banks are grouped into various grading A, B, C, and D, where A grade indicates higher rating and $\mathrm{D}$ grade indicates lower rating. The supervisory ratings of cooperative banks for the last six years (2009-2014) are presented in Table 2.

Table 2

Supervisory Ratings for Co-operative Banks

\begin{tabular}{|c|c|c|c|c|c|}
\hline Supervisory ratings/years & $\begin{array}{l}\text { A } \\
\text { (Grade I) }\end{array}$ & $\begin{array}{l}\text { B } \\
\text { (Grade II) }\end{array}$ & $\begin{array}{l}\text { C } \\
\text { (Grade III) }\end{array}$ & $\begin{array}{l}\text { D } \\
\text { (Grade IV) }\end{array}$ & Total \\
\hline 2009 & 652 & 598 & 295 & 268 & 1,813 \\
\hline 2010 & 748 & 526 & 258 & 238 & 1,770 \\
\hline 2011 & 845 & 484 & 219 & 173 & 1,721 \\
\hline 2012 & 879 & 465 & 179 & 151 & 1,674 \\
\hline 2013 & 845 & 497 & 172 & 131 & 1,645 \\
\hline $2014 *$ & - & - & - & $125 *$ & $1,625^{*}$ \\
\hline
\end{tabular}

Note. * The number of banks under Grade IV and total number of banks for 2014-15 are the projected numbers based on the historical trend analysis using linear regression model.

The banks in D can be described as high risk group based on the sample analysis of supervisory ratings; we find that nearly 125 out of total 1,625 banks are in Grade D indicating a poor financial strength. 
The default rate in urban co-operative banks is really very high as compared to other categories of commercial banks (PSU, Private banks \& Foreign banks). The default rates were estimated by taking into account the number of liquidated banks as against the total number of insured banks for every year. The historical trend analysis produced the following results:

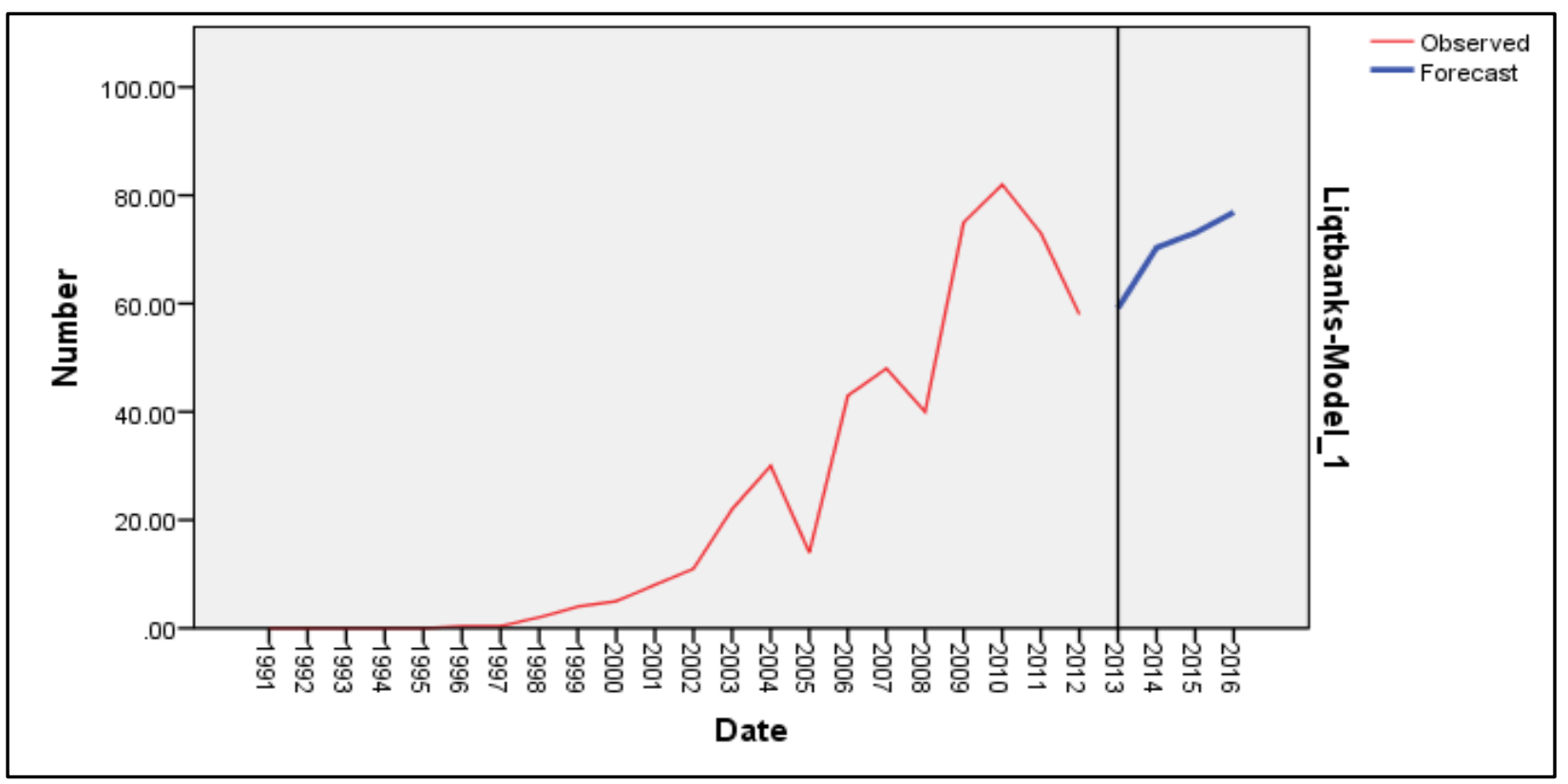

Figure 2. Historical trends of liquidated cooperative banks.

The historical analysis of the liquidated banks depicted in the above chart (Figure 2) shows a steep increase in the number of default rate up to the year 2010 and then has slightly dipped in the year 2011-12. However, looking at the historical pattern over the years suggests that the default rate for the coming years may be likely to go up as indicated/projected by in the above model.

Further number of banks in Grade D (125) accounts for nearly 7.7\% of the total number of banks, which were subjected to RBI evaluation for the year 2014. This provides significantly high rate of default projected for the current year (2014-15). The expected default rate of urban co-operative banks for the year 2014-15 is almost seven times higher than the commercial banks in D Category below CARR of 9.00.

Use of credit risk model for estimating default rate. Looking at the historical trend of the liquidation of the insured banks which had attracted the liability, ARIMA Model was found suitable and tested using the last 25 years historical data of the insured banks from 1991 to 2015. The ARIMA Model produced a reliable fit with an $\mathrm{R} \wedge 2$ of 0.872 and RMSE of 10.84 which indicates a strong statistical significance of the model. The following factors/parameters were also considered to ensure reliable model fit:

(1) Reasonable adequacy of sample size \& time relevance;

(2) Principle changes in deposit insurance system, the composition of the banks-size, type and volume of deposits, exposures, were considered in the model;

(3) The observations cover the different stages of business cycles;

(4) Economic parameters and their impacts were also considered;

(5) The historical trends of liquidated banks and the registered/insured banks of Scheduled Commercial Banks and the Co-operative Banks were considered separately. 


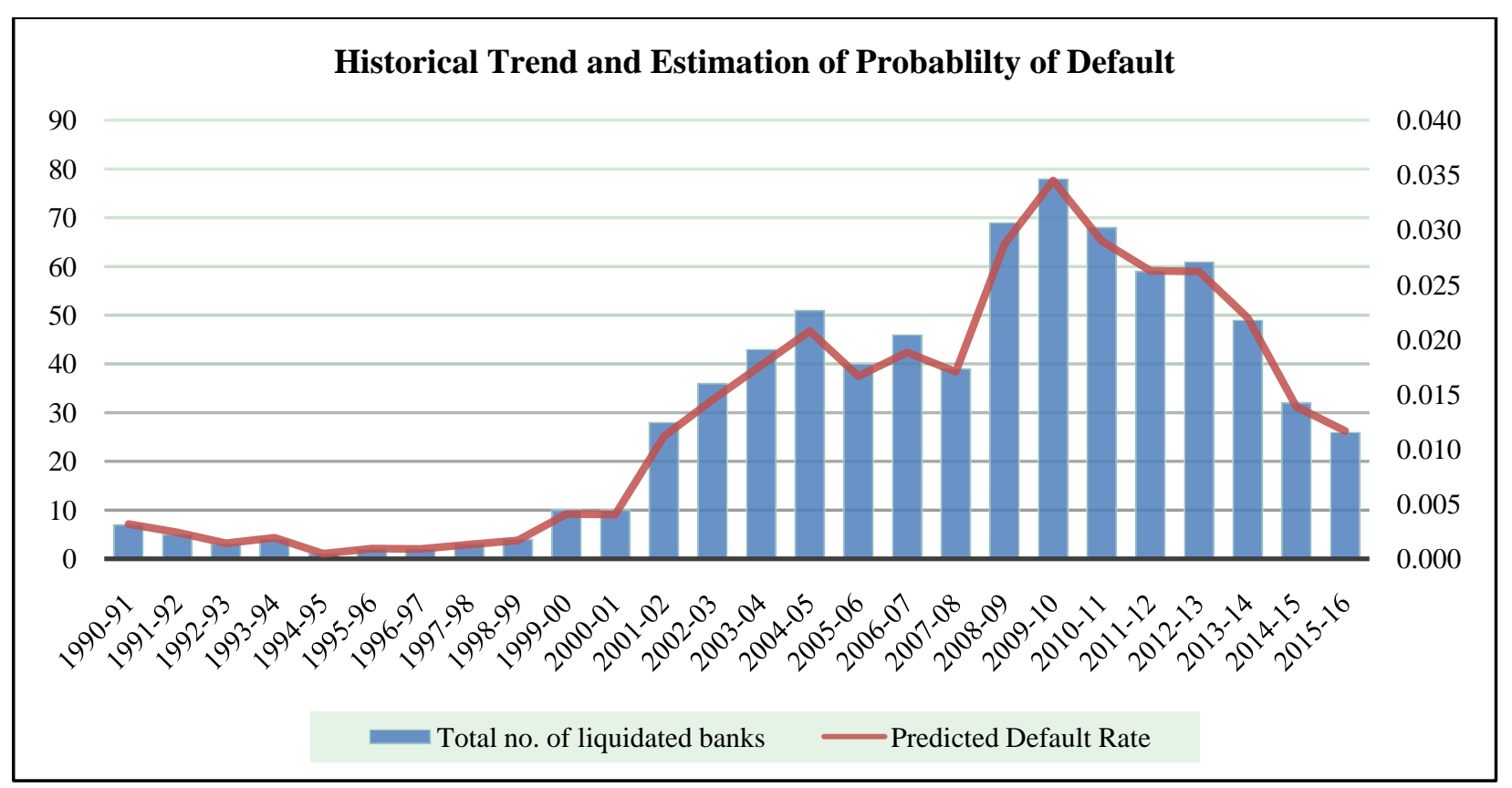

Figure 3. Historical trends of liquidated banks and the predicted trends of ARIMA Model.

It can be seen from the graph (Figure 3) that the historical default of co-operative banks and commercial banks vary drastically, there were only three commercial banks defaulted in the last 10 years while in case of co-operative banks, the historical default rate is almost close to $2 \%$. Hence, two different ARIMA models were run separately to project the future default rates for SCB and co-operative banks. The resulted default rates were applied on the projected insured banks of both SCB's \& co-operative banks separately to obtain the probability of default. The ARIMA model produced a default probability of $0.31 \%$ for the commercial banks and nearly $1.8 \%$ for co-operative banks.

The overall average default rate is $1 \%$ for both commercial and cooperative banks combined as indicated in the above chart.

Claim payouts/Loss at Given Default. Loss at Given Default (LGD) was calculated by applying the probability of default rates on the amount of insured deposits of the insured banks and the claim payouts were estimated by deducting the share of recoveries resulted from the failed banks. Historical amount of Loss at Given Default shows the downward trend for the recent years; the reason seems be the drastic decline in the default rate in Commercial banks and RRBs. However, increase in the rate of exposures among the insured banks suggests that the Loss at Given Default is expected to move in the upward trends for the coming years as the current economic scenario as well as the financial performance of the banks has already indicated a downward trend due to increasing inflation \& money supply which are most likely to impact the performance of small \& medium sized co-operative banks. Accordingly, the forecast of the Loss at Given Default is also in the increasing trend. Secondly, the historical trends of claims payout indicate that the same has been steeply increasing in the last six years (2009-2015). Hence, the projected value of claims outgo/Loss at Given Default is expected to go up in the next two to three years.

As discussed earlier, calculation of Loss at Given Default requires default rate probability and expects loss of insured banks if it results in default and growth of insured deposits. Growth of the insured deposits needs to be 
derived from the growth of assessable deposits since a portion of the insured deposits up to Rs. 100,000/-triggers the liability out of the total assessable deposits. As the historical trend of the assessable deposits indicated an exponential trend, exponential regression model was applied to predict the future deposit growth from the years 2015 to 2016. The results of the model and the predicted values of the assessable deposits are given below in Figure 4 and Table 3.

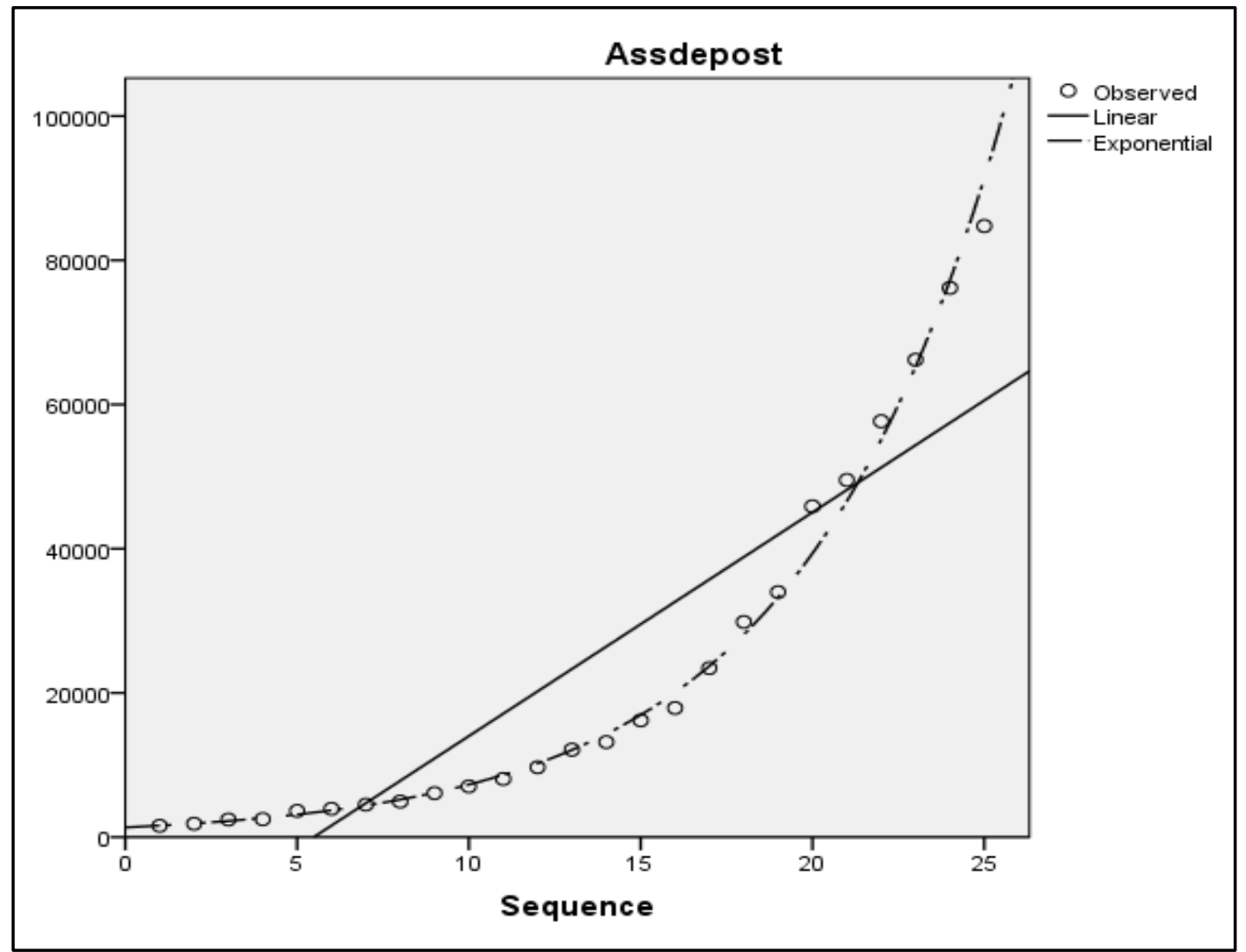

Figure 4. Historical trends of assessable deposits and the predicted trends of exponential model.

Table 3

Model Summary and Parameter Estimates

\begin{tabular}{llllllll}
\hline \multirow{2}{*}{ Equation } & \multicolumn{4}{c}{ Model summary } & \multicolumn{2}{c}{ Parameter estimates } \\
\cline { 2 - 8 } & R square & F & df1 & df2 & Sig. & Constant & b1 \\
\hline Linear & 0.808 & 96.978 & 1 & 23 & 0.000 & $-17,012.480$ & $3,102.982$ \\
Exponential & 0.997 & $7,660.068$ & 1 & 23 & 0.000 & $1,352.772$ & 0.169 \\
\hline
\end{tabular}

Note. Dependent variable is assessable deposit.

Further to validate the model, correlations of macroeconomic variables-Gross Domestic Product and inflation, interest rate movements were done with the historical data of the deposit growth. As GDP has the highest correlation (0.99) with the assessable deposit, the GDP was regressed with the deposit growth (see Table 2 in Appendix 1). Accordingly, the future growth of assessable deposits was projected for the years 2015 to 2016. 


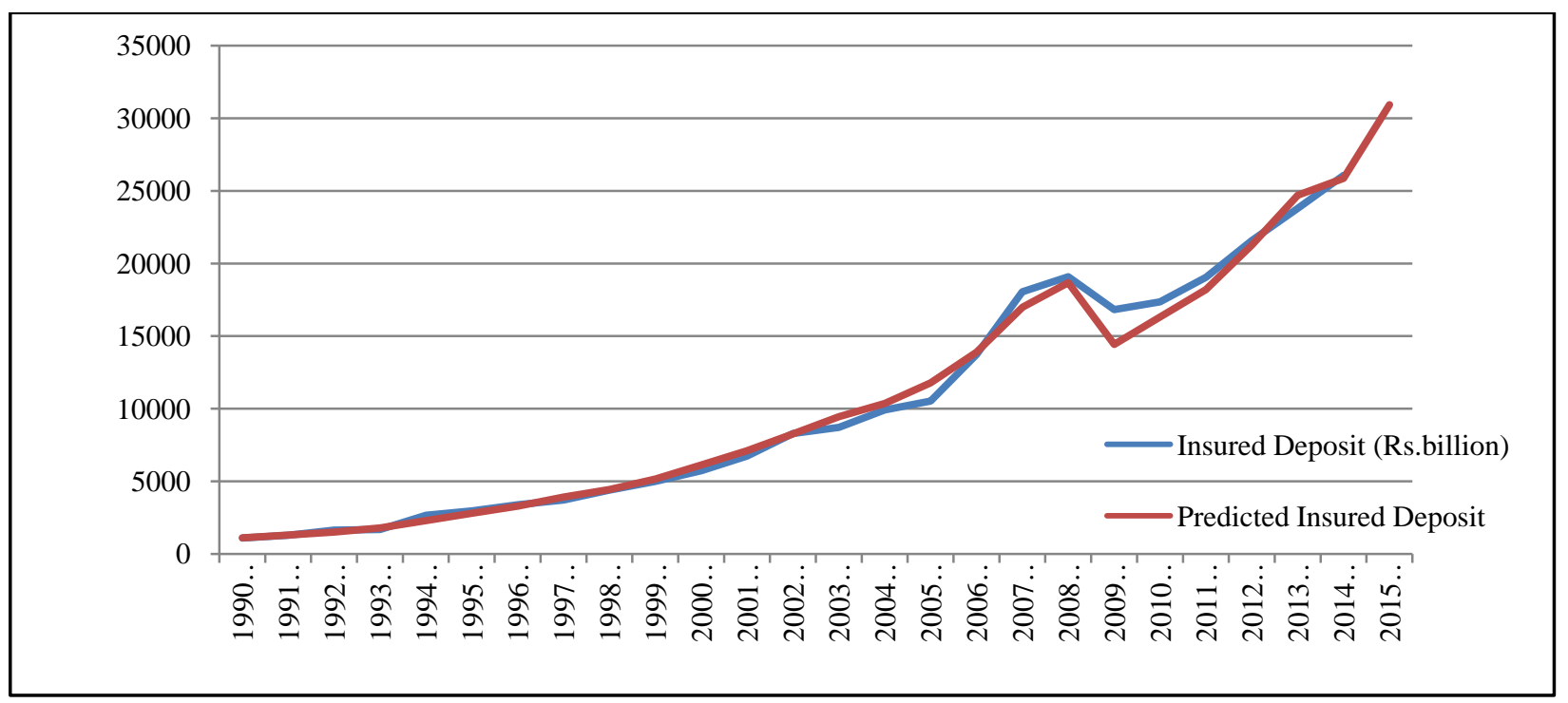

Figure 5. Trend analysis of insured deposits.

As we can infer from the historical data that the ratio of insured deposit to accessible deposit is in the range of 30\% to 33\%, the projected values of insurable deposits for the year 2015-2016 were generated by applying the rate of $30 \%$ on the assessable deposits. The chart (Figure 5) given above indicates the projected values of insured deposits.

It has already been pointed out that the probability of default rate is 0.8 to $1.3 \%$ for the insured banks. Accordingly, the default probability of the insured banks was applied on the projected growth of the insured deposits to obtain the values of Loss at Given Default. The value of LGD is expected to equal the expected losses at the given default of the insured banks under the normal situations where there is no occurrence of systemic risk.

Table 4

Projected Value of LGD Under Normal Scenario

\begin{tabular}{ll}
\hline Year & $\begin{array}{l}\text { Loss at Given Default } \\
\text { (Rs. in billion) }\end{array}$ \\
\hline $2014-15$ & 35.06 \\
$2015-16$ & 36.85 \\
\hline
\end{tabular}

The projected value of LGD for the years 2015 to 2016 has been in the range of Rs. 35.06 to Rs. 36.85 billion (Table 4). The value of LGD is expected to equal to the expected losses at the given default of the insured banks under the normal situations where there is no occurrence of systemic risk. To validate the reliability of the model further, the predicted value of LGD has been compared with the historical values of LGD which has been arrived at by taking into account total amount of claims paid, outstanding claims and the claims reported but not admitted by DICGC. It can be seen from the above chart that the predicted value of LGD almost closely matches with the historical data of total claims data including outstanding claims and IBNA etc. as reflected in Figure 6.

Estimation of Loss at Given Default (LGD) under extreme conditions (worst case scenario). The deposit insurance fund is exposed to both expected losses and unexpected losses. The present LGD/expected loss payouts estimated in the earlier paragraph may be just adequate to cover the insured losses (of both SCBs and CO-op banks) in a normal scenario. However, if the increasing trend of default rates of the co-operative sector in 
the last 10 years is considered, then the present size of LGD may not be adequate to cover such losses. Hence, an attempt has been made to estimate the unexpected loss by taking into account the increasing trend of default of co-operative banks in recent years. The primary objective of this exercise is to check whether the present LGD is adequate to cover such losses, in case if the fund is not adequate, then to create a reserve for meeting the unexpected loss arising out of the failure of higher number of co-operative banks (more than expected) due to a financial crisis impacting the co-operative sector.

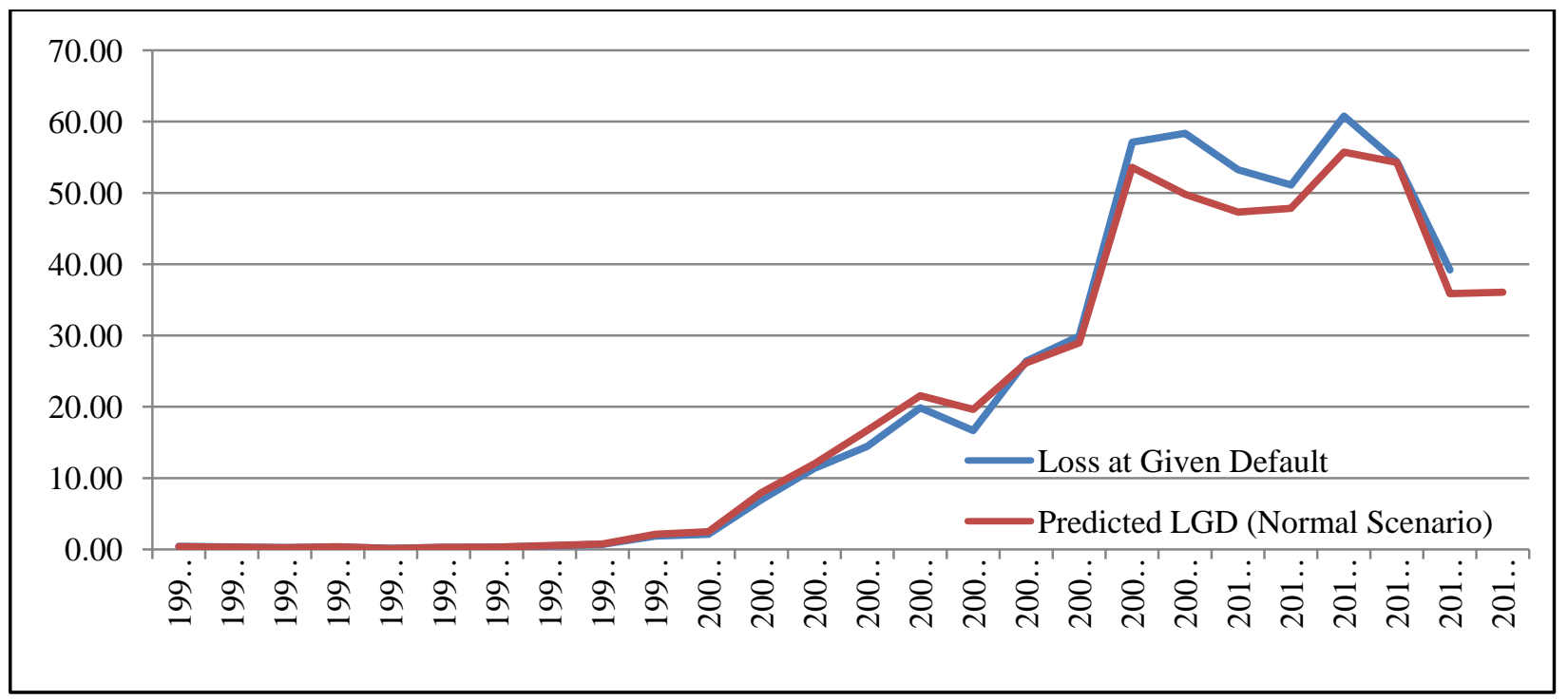

Figure 6. Historical trend and predicted value of Loss at Given Default,

Accordingly, Monte Carlo simulations were used to model the unexpected losses at $1 \%$ level of significance. The simulation uses the default model parameters of Mean and Standard Deviation of losses with random values reflecting the various possible scenarios consisting of unexpected losses including few large losses arising out of a default probability of 1.8\% for the Co-operative Sector. The simulation produced the following results:

It can be inferred from the below chart (Figure 7) that the Loss at Given Default under extreme condition or unexpected loss in worst case scenario is rising sharply in recent years while compared to the value of LGD under normal scenario. This probably indicates that while the number of defaulted banks has come down in recent years due to stricter regulatory prudence and supervision of the banks, however financial market conditions of the country have become highly volatile as we find that the GDP growth has come down from 8\% (in 2011-12) to 6.5\% (in 2013-14) and the interest rate has become highly volatile.

Table 5 suggests that, in order to meet the increasing frequency of default rates of the cooperative banks, DICGC needs to have a reserve equivalent to Rs. 72.04 billion in 2015, and Rs. 78.61 billion in 2016.

Insurance premiums. The main source of Deposit Insurance Fund is premium collected from insured banks. Initially, (during 1995-2000) the rate of premium was fixed at 5 paise for Rs. 100/-(0.05) of assessable deposits. From 2006 onwards, it has been increased to 10 paise for Rs. 100/-. In the last seven years (2007-2014), the assessable deposits have been growing around $20 \%$ while the growth of insured deposits has been around $10 \%$. 


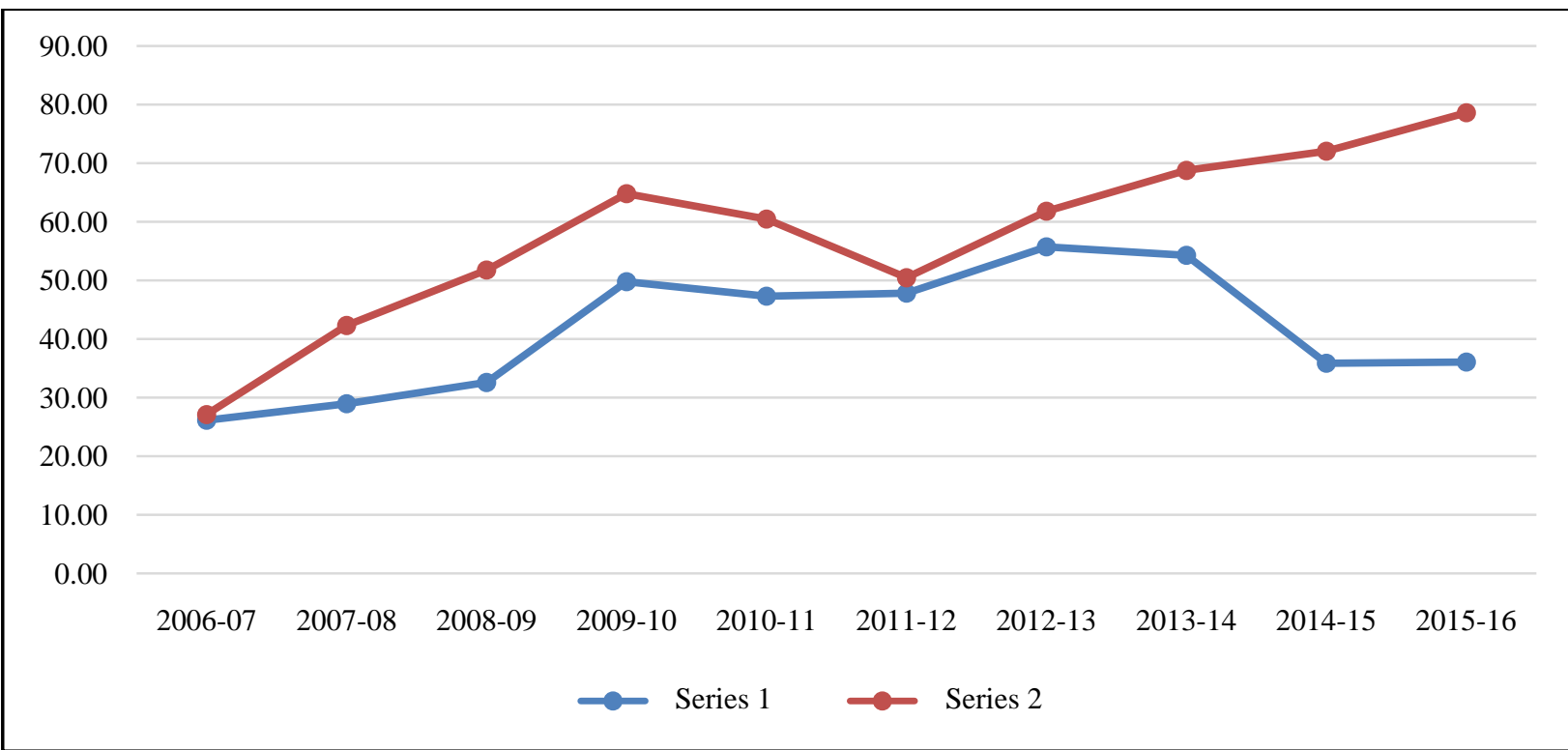

Figure 7. Comparison of LGD normal and extreme conditions. Note. Series 1 refers to LGD under normal scenario and Series 2 indicates the trends under extreme condition.

Table 5

Projected Value of LGD for the Co-operative Sector

\begin{tabular}{lll}
\hline Year & $\begin{array}{l}\text { Loss at Given Default } \\
\text { under normal } \\
\text { (amount in billion) }\end{array}$ & $\begin{array}{l}\text { Loss at Given Default } \\
\text { under extreme } \\
\text { (amount in billion) }\end{array}$ \\
\hline $2014-15$ & 35.87 & 72.04 \\
$2015-16$ & 36.07 & 78.61 \\
\hline
\end{tabular}

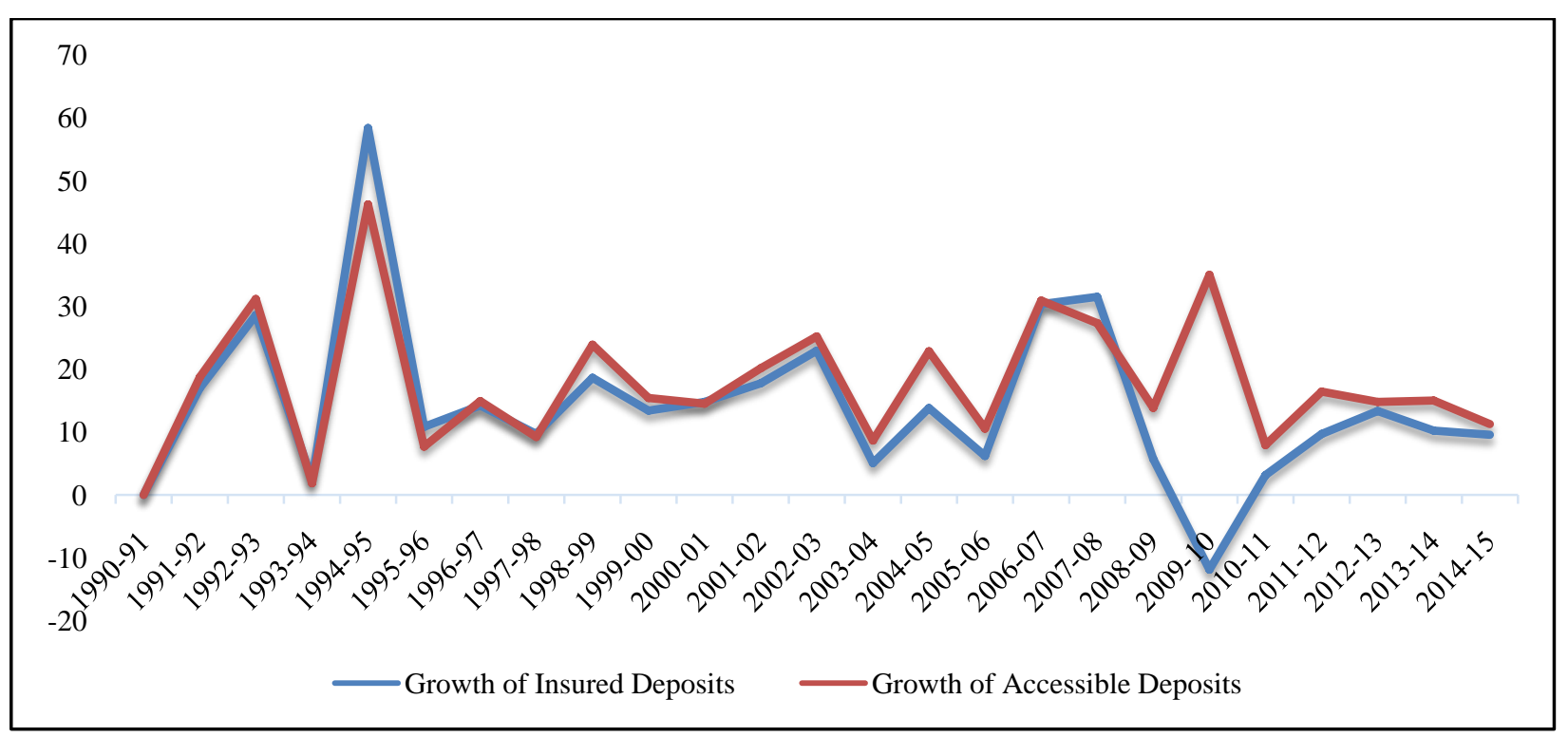

Figure 8. Growth of accessible deposits and insured deposits.

More importantly, as Figure 8 exhibits, the growth of deposits of co-operative banks has been around 30\% which increases the exposure of DICGC to a significantly higher level. Keeping in mind the historical growth of assessable deposits, the projected deposits were estimated using exponential regression model. 
As the premium is charged on the assessable deposit, the projected premiums have been estimated by regressing the historical value of assessable deposit growth. The result of this analysis is clearly visible in Figure 9 enclosed below.

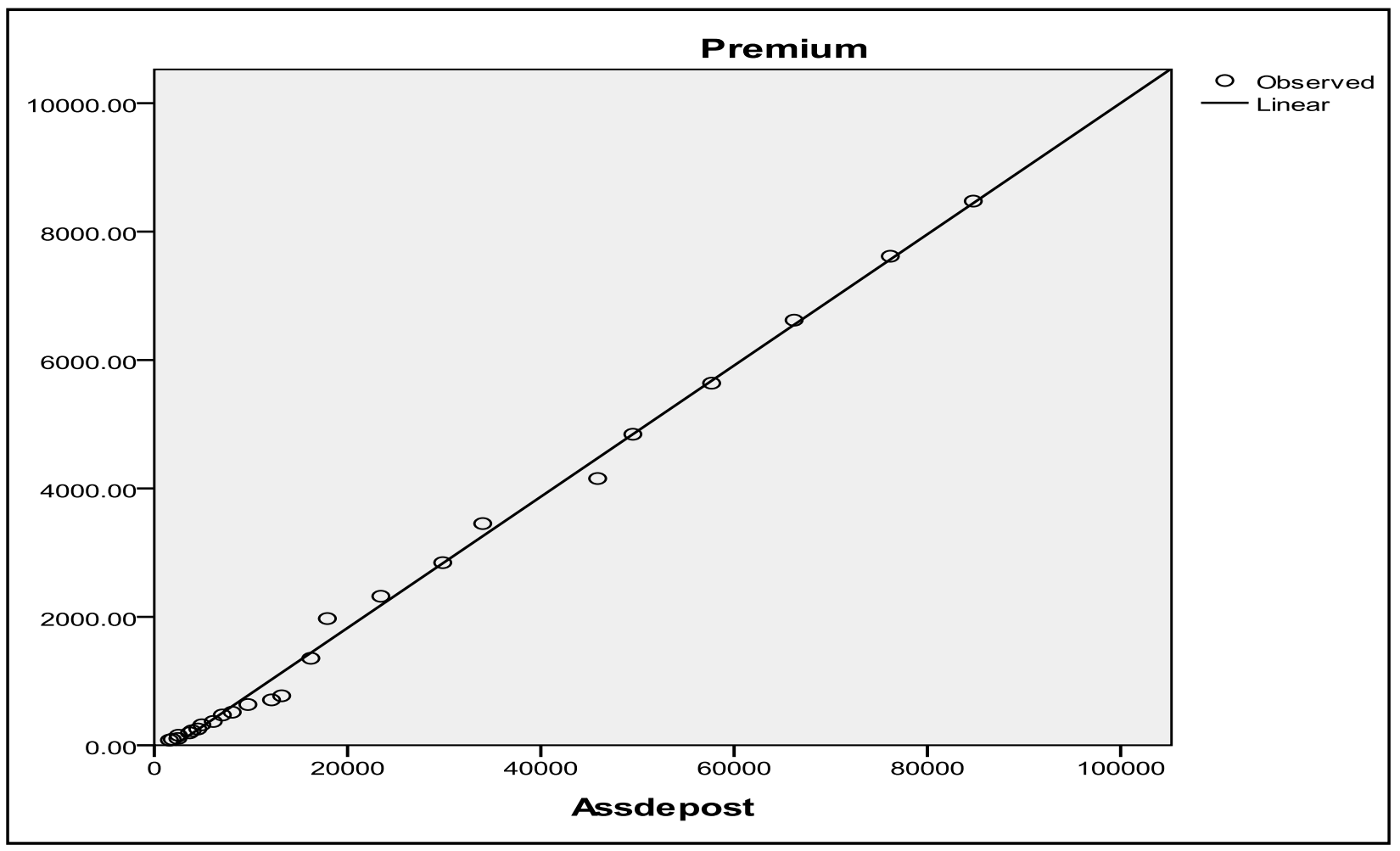

Figure 9. Historical as well as the predicted trend of the premium.

Table 6

Model Summary and Parameter Estimates

\begin{tabular}{|c|c|c|c|c|c|c|c|c|}
\hline \multirow{2}{*}{\multicolumn{2}{|c|}{ Equation }} & \multirow[b]{2}{*}{$\mathrm{R}$ square } & \multicolumn{4}{|c|}{ Model summary } & \multicolumn{2}{|c|}{ Parameter estimates } \\
\hline & & & $\mathrm{F}$ & df1 & df2 & Sig. & Constant & b1 \\
\hline Dimension 1 & Linear & 0.996 & $5,971.589$ & 1 & 23 & 0.000 & -215.416 & 0.102 \\
\hline
\end{tabular}

Notes. The independent variable is assessable deposit; dependent variable is premium.

Figure 9 indicates that the premium predicted by the model closely reflects the historical trends of the premium, reflecting the reliability of the model. Since the historical trend of premium has been linear for the last 25 years, linear model was used to predict premium values for the year 2016 (Table 6). $\mathrm{R}^{2}$ of the linear model is almost 0.99. Further, the correlation between the values of GDP and the premium and the assessable deposits is almost 0.99. The above model forecasts the premium amount of Rs. 96,430 million for the year 2016.

Figure 10 very clearly suggests that the present premium rate (10 paise for Rs. 100/-) is not adequate to cover the probability of default rate even under normal scenario. More importantly, premium income contributes to a large extent in estimating the Deposit Insurance Fund.

Recoveries. It has been observed from the historical data of claims payment that if a bank defaults, it takes on an average two months for DICGC to settle the claims, while the recoveries from the liquidated banks take longer time to reach DICGC. The historical data of recoveries indicate that the rate of recoveries, as a percentage to the claims, in the same year of default, is around $10 \%$ to $15 \%$ and it takes around three to four years to attain the 
maximum recovery of the loss. Further the historical trend of recoveries indicates a downward trend as indicated in Figure 11 suggesting that the downward trend may continue for another two to three years.

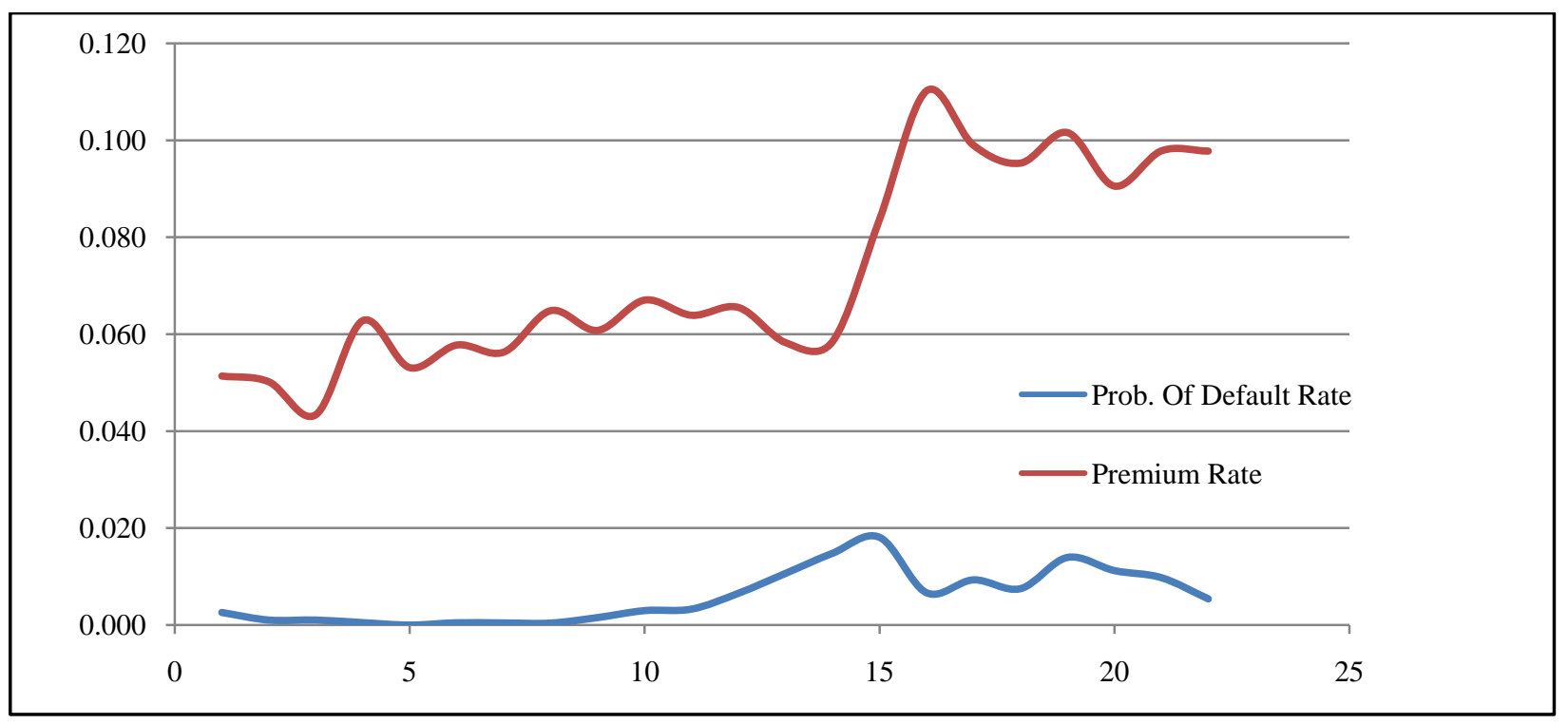

Figure 10. Premium rates vs. Prob. of default.

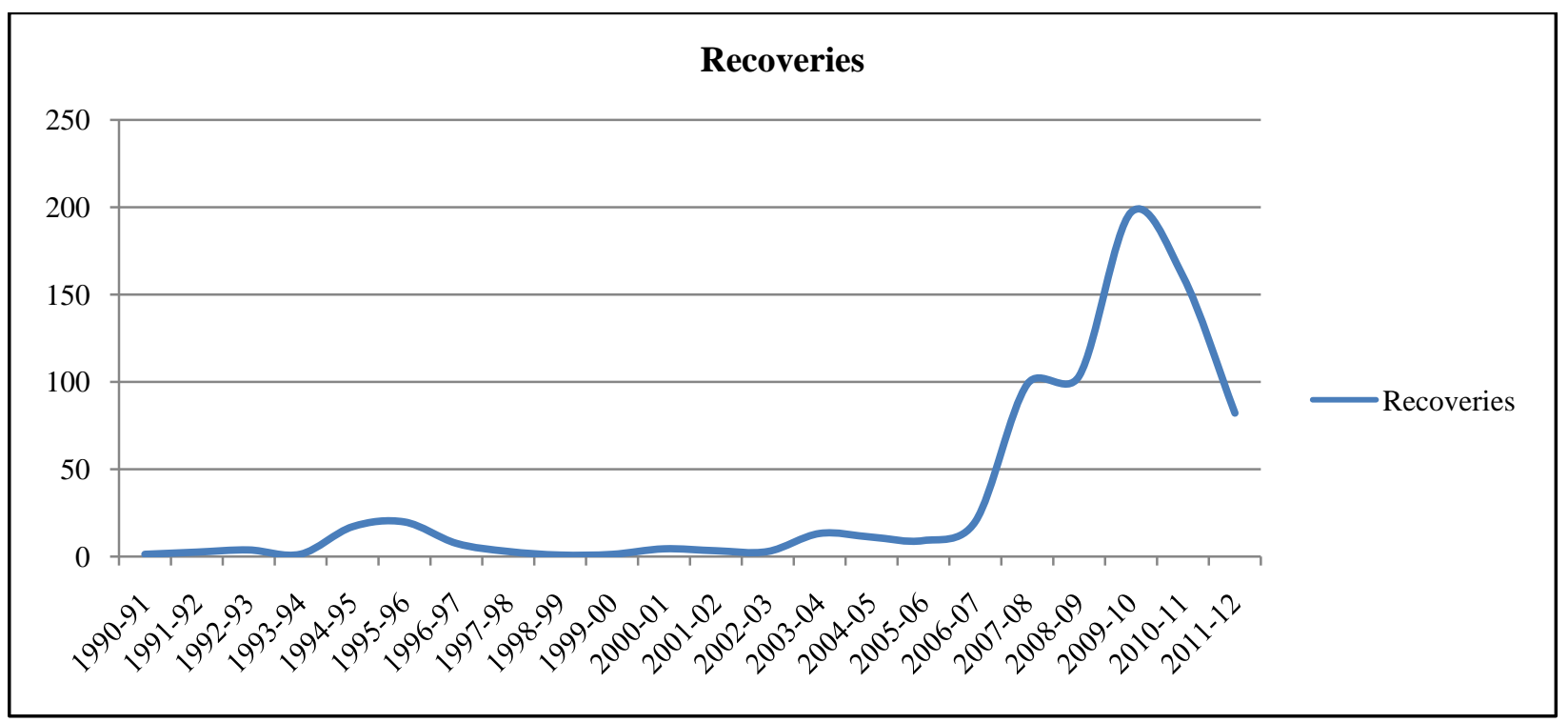

Figure 11. Historical trends in recoveries.

This also almost correlates with the forecasted trend of LGD under normal scenario. This suggests that the size of Deposit Insurance Fund needs to be enhanced adequately to meet the losses arising under extreme or worst case scenario.

Investment income. The main source of investment income is the volume of premium income that DICGC collects from the insured banks. Premiums are received in the beginning of the Registration or Financial Year and they are being collected once in every six months. The investment fund consists of premium collected during the year, the opening balance of Deposit Insurance Fund including surplus earned in the previous year and the recoveries. The coupon income received from Government Securities is also expected to be reinvested. Nearly 
$100 \%$ of the investable fund of DICGC has been invested in the Government Securities. Though the historical trend of the investment return indicates an average return of $8 \%$, considering the present market conditions as well as the value of impairment and amortization expenses, the expected return for the year 2016 has been estimated as $6 \%$ approximately.

After projecting the values of all the aforesaid parameters constituting the Deposit Insurance Fund, the next step is to estimate the Deposit Insurance Fund required to meet the losses arising under normal as well as extreme or worst case scenario. The next paragraph discusses the estimation of Deposit Insurance Fund.

\section{Estimation of Deposit Insurance Fund}

As discussed in the methodology, the Deposit Insurance Fund was estimated using the aforesaid parameters: default probability, Loss at Given Default (LGD), the associated losses arising out of failure of the insured banks /expected claim payouts, premium income, recoveries from liquidation of the failed banks, investment income and the operational expenses of DICGC incurred for administering the deposit insurance scheme.

Each of the above parameters was inputted into a model using the following formula:

$\mathrm{B}_{\mathrm{t}}=\mathrm{B}_{\mathrm{t}-1}+\mathrm{P}_{\mathrm{t}}+\mathrm{R}_{\mathrm{t}}+\mathrm{I}_{\mathrm{t}}-\mathrm{LGD}_{\mathrm{t}}-\mathrm{E}$

Where $B_{t}$ denotes the Deposit Insurance Fund for current year $(t)$

$\mathrm{B}_{\mathrm{t}-1}=$ Initial balance of fund

$\mathrm{P}_{\mathrm{t}}=$ Premium income received from insured banks

$\mathrm{R}_{\mathrm{t}}=$ Recoveries from liquidation of the failed banks

$\mathrm{I}_{\mathrm{t}}=$ Investment income

$\mathrm{LGD}_{\mathrm{t}}=$ Claims payouts made to the deposit holders of the failed banks

$\mathrm{E}=$ Operational expenses of DICGC

Each of the above parameters was inputted into an appropriate econometric model: ARIMA using the historical trends of the data. The model produces the forecasted values of these parameters for the next two years (2015-2016). As suggested in the credit model literatures, the inflows (premiums, investment incomes, and recoveries) and outflows (claim payouts) of the fund have been treated as stochastic variables. Then, the generated parameters of the model were simulated using Monte-Carlo method (Box Muller Algorithm) to generate expected Deposit Insurance Fund value.

The above model was validated with the historical data of these parameters along with the Deposit Insurance Fund value estimated by DICGC. The model produces both the historical as well as the predicted Deposit Insurance Fund value which is given in the following table as well as in Figure 11.

Figure 12 produced by the ARIMA Model highlights reliability of the model fit as we see right from 1991 to 2015, the predicted line almost follows very closely with the historical trend while it is distracted only for a period of five years (2000 to 2005) which may possibly be due to certain structural changes introduced by DICGC in estimating the fund value during the period. Further, the predicted Deposit Insurance Fund value was also validated through Statistical Significance Test at $5 \%$ as well as $1 \%$ level of significance. The ARIMA Model produced a predicted value of 511.09 billion for the year 2015 to 574.32 billion for 2016 .

Figure 12 and Table 7 exhibit the projected values of Deposit Insurance Fund for the year 2015-2016. These values may be quite relevant only under normal market conditions (Normal scenario), and this projected fund value does not consider the systematic risk or the catastrophic events triggering unexpected loss. 


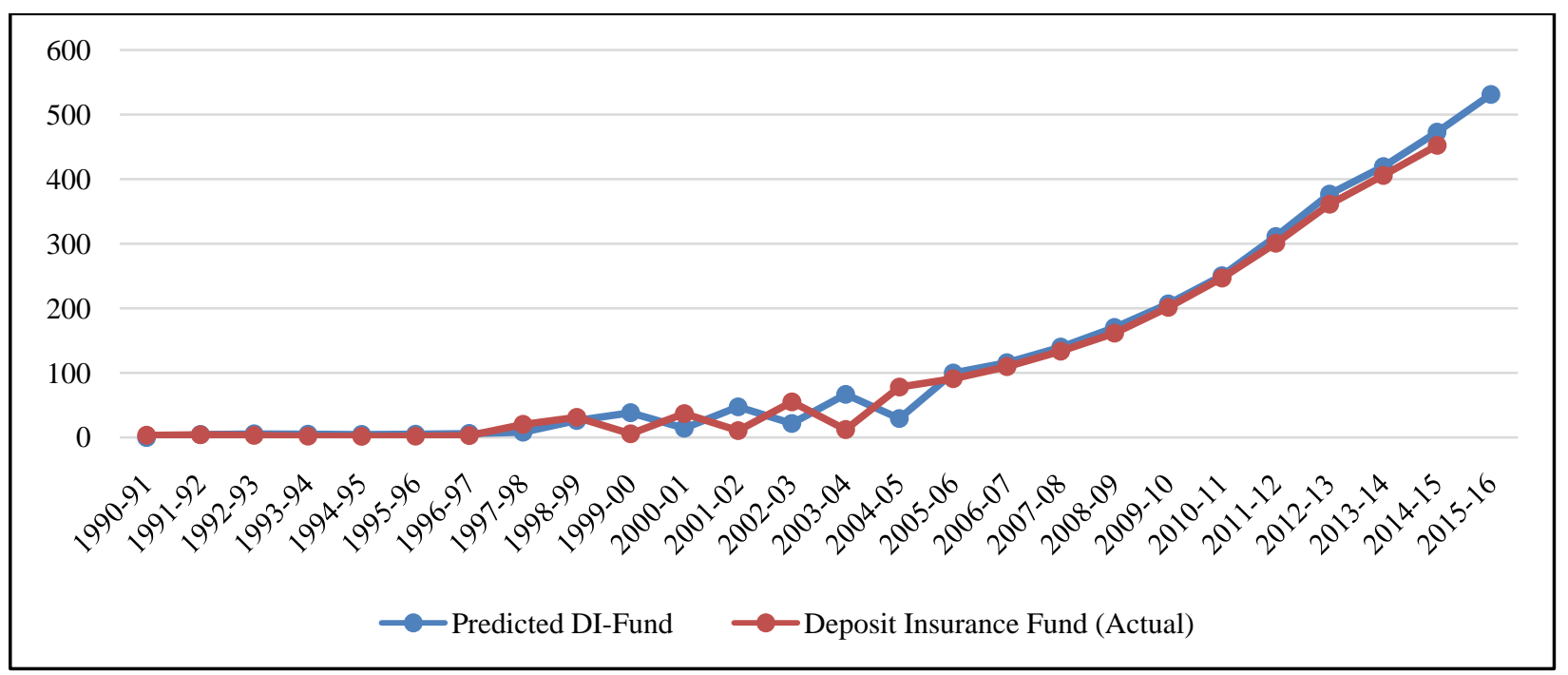

Figure 12. Historical trend of deposit insurance fund \& projected fund under normal scenario.

Table 7

Projected Value of Deposit Fund Under Normal Scenario

\begin{tabular}{ll}
\hline Year & $\begin{array}{l}\text { Deposit insurance fund } \\
\text { (amount in Rs. billion) }\end{array}$ \\
\hline $2014-15$ & 511.09 \\
$2015-16$ & 574.32 \\
\hline
\end{tabular}

\section{Determining a Reserve for Unexpected Losses (Worse Case Scenario)}

As suggested earlier, the deposit insurance fund is exposed to both expected losses and unexpected losses and the present fund size may be just adequate to cover the insured losses in a normal situation. However, if there is a systemic risk or catastrophe events, the present fund size may not be adequate. Hence, a separate fund needs to be created for meeting such unexpected losses.

Determining a reserve for unexpected losses-assigning a portion of a reserve to cover unexpected losses is even more challenging than dealing with estimating a provision for expected losses. The major difference from modeling expected losses is that one must utilize a different technique for modeling default probabilities. An increasingly common approach to do this is use of Monte Carlo estimation techniques (e.g. Singapore and Canada, IADI, 2009). This is a modeling approach or technique that draws on some characteristics of membership, as well statistics on defaults and losses to estimate failure probabilities and resulting losses. Analysis is based on the premise that financial resources of Rs. $\mathrm{X}$ are expected to cover losses in all but $(1-\mathrm{Y}) \%$ of the time (where $\mathrm{Y}$ is the confidence interval).

Monte Carlo simulations essentially model a year in the life of a deposit insurer many times over to build a picture of the various probabilities of loss and a loss distribution facing a deposit insurer without making assumptions about individual banks (Rosalind, 2001). By running literally thousands of trials, the analysis estimates a loss distribution from which reserve levels can be determined for different confidence intervals. One of the widely used confidential intervals $99 \%$ or (1-99\%) is $1 \%$ level of significance.

Accordingly, in this study, to estimate the fund value under worst case scenario, the fund value was estimated at $1 \%$ level of significance using Monte Carlo simulation. The model predicts a simulated default probability of $5.36 \%$ for Co-operative Banks and $2 \%$ for SCBs in a worst case scenario. 


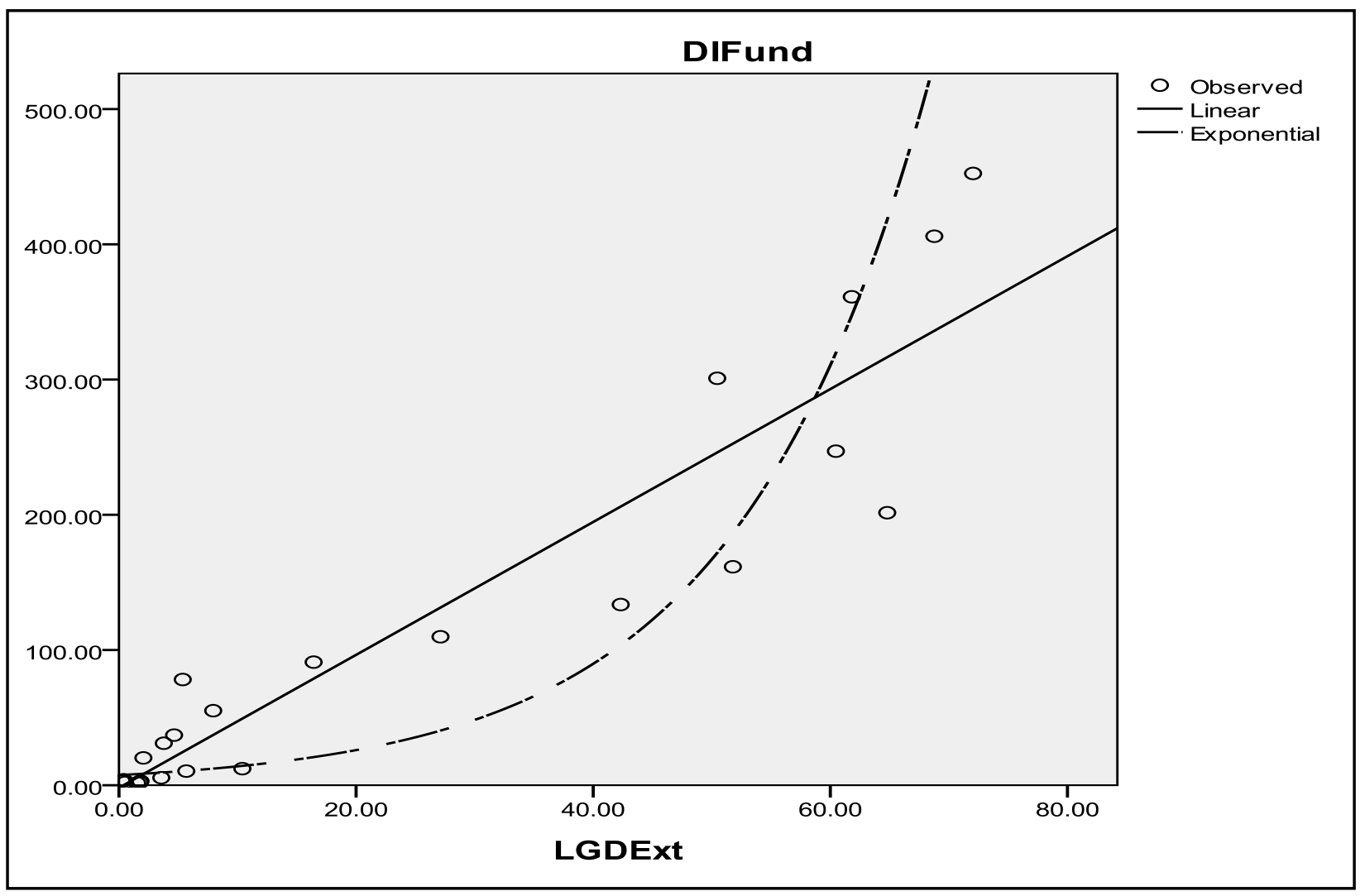

Figure 13. Estimation of deposit insurance fund under worse scenario.

Table 8

Model Summary and Parameter Estimates

\begin{tabular}{llllllll}
\hline \multirow{2}{*}{ Equation } & \multicolumn{4}{c}{ Model summary } & \multicolumn{3}{c}{ Parameter estimates } \\
\cline { 2 - 9 } & R square & $\mathrm{F}$ & $\mathrm{df1}$ & $\mathrm{df2}$ & Sig. & Constant & b1 \\
\hline Linear & 0.879 & 167.147 & 1 & 23 & 0.000 & -1.873 & 4.914 \\
Exponential & 0.732 & 62.947 & 1 & 23 & 0.000 & 7.514 & 0.062 \\
\hline
\end{tabular}

Notes. The independent variable is LGDExt; dependent variable is DIFund.

The simulated value of LGD at worst case scenario (at 1\% level significance) was used to predict the Deposit Insurance Fund value for the worst case scenario. Accordingly, the simulated value of LGD was regressed on the Deposit Insurance Fund value using both linear as well as exponential regression model (Table 8). Trend analysis of the output of both the model (Figure 13) suggested combining the output to generate the deposit fund value for the worst case scenario. The above model predicts a value of nearly Rs. 655.31 billion for the year 2015-16 and Rs. 984.98 billion for the year 2016-2017.

\section{Adequacy of Deposit Insurance Fund Liability}

As we discussed earlier, Target Reserve Ratio (TRR) is generally used as the measure to check the adequacy of Deposit Insurance Fund liability. Here, the estimated Deposit Insurance Fund using the above model can be used as one of the primary determinants where the ratio of the estimated fund value to the insured deposit, would provide the expected TRR to validate the adequacy of Deposit Insurance Fund Liability.

Figure 14 indicates that the historical trends of the actual TRR and the predicted TRR which are really very close almost from the year 1990 to 1999 and again from 2006 to 2012 except the period from 2000 to 2005; the 
predicted TRR also moves in the same direction with that of the historical trend, prove the statistical significance of the model. The predicted TRR suggests that the value of Deposit Insurance Fund requires to maintain the present TRR of 1.90, shall be around Rs. 504 billion for the 2015 and the corporation needs to have Rs. 530 billion to maintain the TRR to 2.00. More importantly, the estimated Deposit Insurance Fund considers only the expected value of losses arising out of the failure of banks, but it does not take into account unexpected loss which may arise if there is occurrence of systemic risk/economic recession or severe bank failure. Hence, it has been suggested that higher TRR of 2.75 to 3.00 may be provided to meet the unexpected losses if arise in the near future. It is worthwhile to note the point that most of the Deposit Insurance Corporations in the Asia Pacific countries maintain TRR up to 2.5\% (CDIC, 2003), While Russia, Azerbaijan, and Kazakhstan maintain a TRR of $5 \%$. Internationally, the work of estimating adequate rate of TRR is still going on (Lee \& Ashley, 2010). The IADI has set up a Sub Group under its research and guidance committee for developing a guidance note for the member banks on setting up Target Funds.

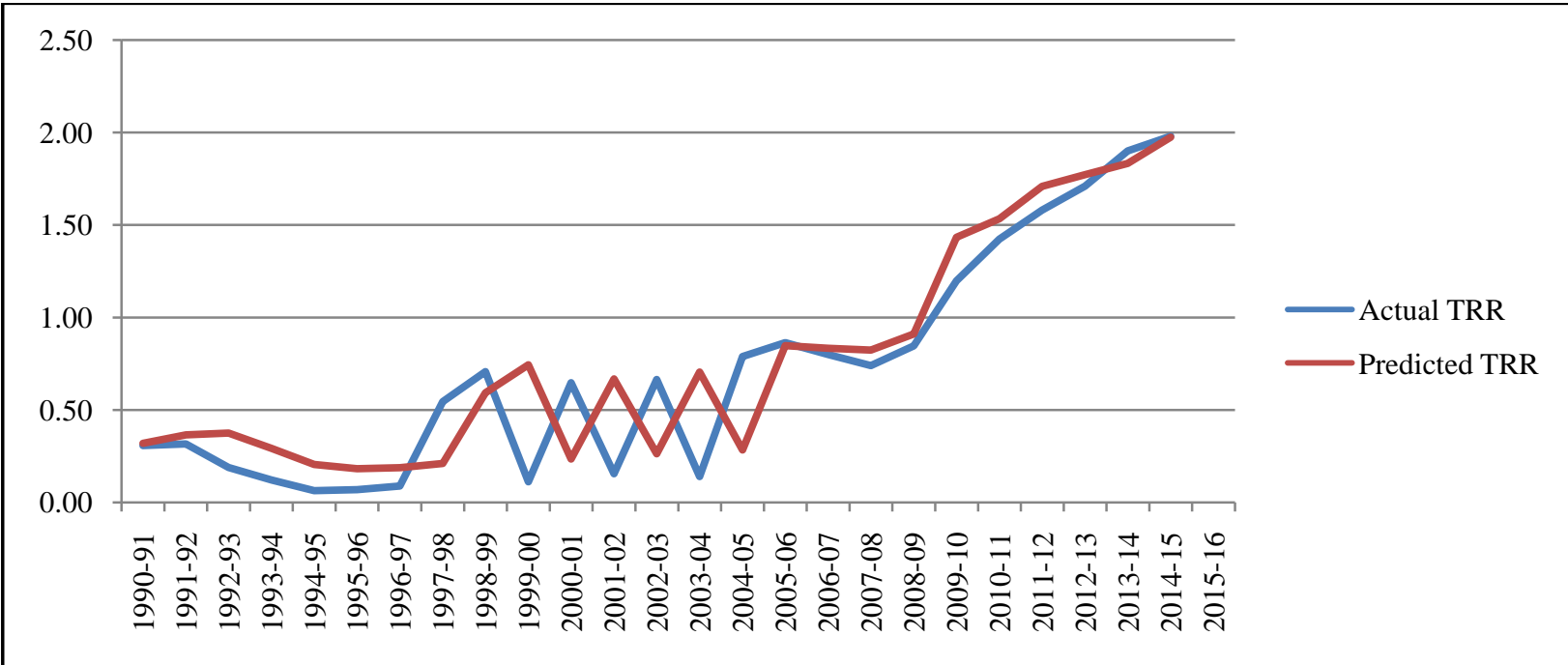

Figure 14. Predicted deposit insurance fund.

\section{Managerial Implications and Suggestions}

(1) Since the risk profile of various types of bank is different, particularly co-operative banks have much greater default rate than SCB, co-operative banks require a higher size of fund than others. Hence, an additional fund needs to be created for meeting the liabilities arising out of increasing rate of failures in the co-operative banks.

Separate/additional funds can help in identifying the sectors with significantly different risk profiles and reducing the scope of cross subsidies between the sectors. While common costs can be shared, sector specific costs can be isolated and premiums can vary among sectors.

(2) The deposit insurance fund is exposed to both expected losses and unexpected losses and the present fund size may be just adequate to cover the insured losses in a normal situation. However, if there is a systemic risk or catastrophe of events occurs, the present fund size may not be adequate. Hence, a separate/additional fund needs to be created for meeting the unexpected loss arising out of occurrence of systemic risk/collapse of systems or banking system failures. 
(3) Though an attempt has been made in this paper to estimate Loss at Given Default and require Deposit Fund to meet the losses arising in a worst case scenario at 1\% level of significance, estimation of unexpected losses requires an extreme Loss Distribution Model to be built and the results of the model need to be simulated under different scenarios impacting Deposit Insurance Fund. It has been suggested to develop such extreme loss distribution model to estimate unexpected losses.

(4) The current size of TRR maintained by DICGC may be good enough to cover the expected losses in a normal risk condition. But, however, if there is an occurrence of systemic risk, then the current TRR may not be adequate to cover the unexpected losses that may be triggered when there are more than expected numbers of bank failures occurred at single time. Hence, it may be advisable to keep 3\% TRR rather than 1.9\%. Even the activities of Deposit Insurance Corporation (DICGC) itself and the regulatory changes etc. can affect the Deposit Insurance Fund adequacy. Hence, most of the countries have a TRR around 2\% particularly developing countries like Brazil, Jamaica, and Indonesia etc. (IADI, 2009).

(5) The present study estimated the default probability of the insured banks based on the historical data of default and the associated losses paid by DIGGC. The study does not cover the financial performance measures of the insured banks and their associated relationship with bank failures due to non-availability of data. It may be worthwhile, while measuring the default risks of the insured banks, a large number of factors need to be taken into account including the composition of banks (Number, Size, and Lines of Business), the quality of assets and liabilities, financial performance, and their exposure, the probability of failures and the associated losses that the insurer can expect. Hence, it has been suggested that a detailed study of the above factors and their relationship with the risk of default would help in estimating the default probability with better accuracy.

(6) Management of Deposit Insurance Funds: It has been observed that almost $100 \%$ of the fund is invested by the corporation in government securities, since it may be a prudent policy to maintain certain percentage of the fund invested in liquid assets. When a deposit insurance system is primarily funded on an ex-ante basis, policymakers need to consider what investment or portfolio management policy to pursue. There is a trade-off between liquidity and return. A fund must have an adequate level of liquid assets on hand to enable it to readily compensate insured depositors, if an institution fails. Depending on the mandate of the insurer, funds may also be required to support other forms of failure resolution. Funds will also be necessary to support the day-do-day operations and to attract staff and the operational resources necessary for the functioning of the corporation (In India, government securities have high level of liquidity; moreover, in case of DICGC the fund requirement is not on an immediate basis as there is gap between the times. The bank is put on moratorium and the payment of the insurance to the depositors).

In many countries the funds are held in low-risk, highly liquid assets-typically short-term government securities. This approach is used in countries such as Brazil, Canada, and Finland and is by far the most common one.

(7) Reinsurance through catastrophe bonds: (securitization of deposit insurance losses). Risk transfers are routinely performed in the property and casualty insurance business through reinsurance contracts obtained from reinsurance companies. The insurance industry has thus been naturally attracted to financial markets to solve its capital needs and a trend has developed towards securitization of insurance risks. More specifically, in the case of catastrophic risks, new instruments such as catastrophe bonds and catastrophe options have been created. A catastrophe bond is similar to a standard bond, except that if a specified catastrophic event occurs, then the bond is not redeemed. In this way, the bondholder acts as an insurer with respect to the catastrophe. 
Also, the bond mechanism eliminates the credit risk from the point of view of the insured party (IADI, 2009).

A deposit insurance system runs a catastrophic risk as much as it is faced with fairly low probabilities of potentially large losses. The risk transfer technique used in property and casualty insurance could be transposed to the deposit insurance context and a deposit insurer could transfer part of its risks by issuing financial catastrophe bonds. Those bonds would not be redeemed if losses of the deposit insurance agency exceed some fixed amount during a specified period of time.

(8) Risk transfers through credit derivatives. Derivative securities have recently been introduced to trade credit risk. Swaps of different varieties have become the preferred method to trade credit risks: the three main types are the total return swap, the credit default swap, and the credit default exchange swap (IADI, 2009). Under the first two types, one party to the transaction buys protection for credit losses from another party and thus the reduction of risk involves a cash outflow. Under the third type, two parties exchange credit exposures and if the two exposures are similar, the contract may be entered into without any cash outlay. This latter type of contract, which would involve a swap between two insurers, seems the most interesting for deposit insurance agencies. Banks are now permitted by the RBI to deal in CDS; however, Indian market will have to be developed to trade in this complex derivative product.

\section{References}

Beat, B., \& Susanna, W. (2009). Design, structure and implementation of a modern deposit insurance scheme. The European Money and Finance Forum. Vienna.

Canada Deposit Insurance Corporation. (2003). International Deposit Insurance Survey, (Ottawa: CDIC), World Bank.

Daniel, P. (2004). Estimating probabilities of default for German savings banks and credit cooperatives. Deutsche Bundes Bank.

International Association of Deposit Insurers. (2009). Funding of deposit insurance systems. Guidance Paper. IADI, Basel, Switzerland.

International Association of Deposit Insurers. (2009). Evaluation of deposit insurance fund sufficiency on the basis of risk analysis-IADI, Basel, Switzerland. Discussion Paper.

International Association of Deposit Insurers. (2011). Funding mechanism of deposit insurance systems in the Asia-Pacific regions, Basel, Switzerland. APRC Funding Research Paper.

Judy, R. (2007). The fair value of the federal deposit insurance guarantee. Congressional Budget Office, W. D. C.

Lee, K. D., \& Ashley, M. C. (2010). Toward a long-term strategy for deposit insurance fund management. FDIC Quarterly, 4(4). Rosalind, L. B. (2001). Evaluating the adequacy of the deposit insurance fund: A credit-risk modeling approach. Working Paper.

Sergey, S., Alexander, D., Roman, R., Alexey, B., Vladimir, Z., \& Alexey, G. (2005). Credit risk modelling for assessing deposit insurance fund adequacy: The case of Russia. Working Paper.

The Monetary Authority of Singapore. (2002). Deposit insurance scheme. Consultation Paper. 


\section{Appendix 1}

Table 1

Macro Economic Variables for the Historical Period (1991 to 2014)

\begin{tabular}{|c|c|c|c|c|c|c|}
\hline Year & $\begin{array}{l}\text { GDP (At CP) in } \\
\text { billion }\end{array}$ & $\begin{array}{l}\text { GDS (At CP) in } \\
\text { billion }\end{array}$ & Credits & Key lending rates & $\begin{array}{l}\text { Inflation CPI } \\
\text { (IW) }\end{array}$ & $\begin{array}{l}\text { Interest rates } \\
\text { (five yrs \& } \\
\text { above) }\end{array}$ \\
\hline 1990-91 & $5,862.12$ & $1,344.08$ & 20.4 & 16 & 11.6 & 11 \\
\hline 1991-92 & $6,738.75$ & $1,435.3$ & 19.2 & 19 & 13.5 & 13 \\
\hline 1992-93 & $7,745.45$ & $1,646.21$ & 20.2 & 17 & 9.6 & 11 \\
\hline 1993-94 & $8,913.55$ & $1,929.94$ & 19 & 14 & 7.5 & 10 \\
\hline 1994-95 & $10,455.9$ & $2,466.68$ & 20.8 & 15 & 10.1 & 11 \\
\hline 1995-96 & $12,267.25$ & $2,892.65$ & 21.3 & 16.5 & 10.2 & 12 \\
\hline 1996-97 & $14,192.77$ & 3,183.87 & 20.2 & 15 & 9.4 & 13 \\
\hline 1997-98 & $15,723.94$ & $3,797.9$ & 21.2 & 14 & 6.8 & 12 \\
\hline 1998-99 & $18,033.78$ & $4,181.59$ & 21.1 & 13 & 13.1 & 11.5 \\
\hline 1999-00 & $20,121.98$ & $5,168.46$ & 22.3 & 12.5 & 3.4 & 10.5 \\
\hline 2000-01 & $21,686.52$ & $5,155.45$ & 24.3 & 12 & 3.8 & 10 \\
\hline 2001-02 & $23,483.3$ & $5,853.75$ & 25.9 & 12 & 4.3 & 8.5 \\
\hline 2002-03 & $25,306.63$ & $6,562.29$ & 29.7 & 11.5 & 4 & 6.25 \\
\hline 2003-04 & 28,379 & $8,237.75$ & 30.5 & 11 & 3.9 & 5.5 \\
\hline 2004-05 & $32,422.09$ & $10,507.03$ & 33.9 & 11 & 3.8 & 6.25 \\
\hline 2005-06 & $36,933.69$ & $12,351.51$ & 40.8 & 12.75 & 4.4 & 7 \\
\hline 2006-07 & $42,947.06$ & $14,859.09$ & 45 & 14.75 & 6.7 & 9.5 \\
\hline 2007-08 & $49,870.9$ & $18,363.32$ & 47.4 & 15.75 & 6.2 & 8.75 \\
\hline 2008-09 & $56,300.63$ & $18,026.2$ & 49.3 & 16.75 & 9.1 & 8.5 \\
\hline 2009-10 & 64,778 & 21,829.7 & 50.2 & 15.75 & 12.2 & 7.5 \\
\hline 2010-11 & $77,841.15$ & $24,819.31$ & 51.4 & 9.5 & 10.5 & 8.75 \\
\hline 2011-12 & $90,097.22$ & $28,244.59$ & 52.1 & 10.75 & 8.4 & 9.25 \\
\hline 2012-13 & $101,132.82$ & $30,434.74$ & 53.2 & 10.5 & 10.2 & 9.0 \\
\hline 2013-14 & $113,550.73$ & $34,519.42$ & 51.2 & 10.5 & 9.5 & 9.10 \\
\hline
\end{tabular}

Note. RBI's database on Indian Economy. 
Table 2

Macro Economic Variables and Their Relationship With Deposit Insurance Parameters

\begin{tabular}{|c|c|c|c|c|c|c|c|c|}
\hline & & $\begin{array}{l}\text { GDP (At } \\
\text { CP) in } \\
\text { billion }\end{array}$ & $\begin{array}{l}\text { GDS (At } \\
\mathrm{CP} \text { ) in } \\
\text { billion }\end{array}$ & $\begin{array}{l}\text { Key lending } \\
\text { rates }\end{array}$ & Credit & $\begin{array}{l}\text { Total assess } \\
\text { deposit (Rs. } \\
\mathrm{Cr} \text { ) }\end{array}$ & $\begin{array}{l}\text { CPI annual } \\
\text { average } \\
\text { variation (IW) }\end{array}$ & $\begin{array}{l}\text { Bank deposit } \\
\text { rates } \\
\text { (above five yrs) }\end{array}$ \\
\hline \multirow{3}{*}{$\begin{array}{l}\text { GDP (At CP) } \\
\text { in billions }\end{array}$} & $\begin{array}{l}\text { Pearson } \\
\text { correlation }\end{array}$ & 1 & 0.995 & -0.389 & 0.952 & 0.993 & -0.017 & -0.479 \\
\hline & Sig. (2-tailed) & & 0.000 & 0.073 & 0.000 & 0.000 & 0.939 & 0.024 \\
\hline & $\mathrm{N}$ & 22 & 22 & 22 & 22 & 22 & 22 & 22 \\
\hline \multirow{3}{*}{$\begin{array}{l}\text { GDS (At CP) } \\
\text { in billions }\end{array}$} & $\begin{array}{l}\text { Pearson } \\
\text { correlation }\end{array}$ & 0.995 & 1 & -0.336 & 0.972 & 0.991 & -0.006 & -0.485 \\
\hline & Sig. (2-tailed) & 0.000 & & 0.126 & 0.000 & 0.000 & 0.977 & 0.022 \\
\hline & $\mathrm{N}$ & 22 & 22 & 22 & 22 & 22 & 22 & 22 \\
\hline \multirow{3}{*}{$\begin{array}{l}\text { Key lending } \\
\text { rates }\end{array}$} & $\begin{array}{l}\text { Pearson } \\
\text { correlation }\end{array}$ & -0.389 & -0.336 & 1 & -0.253 & -0.322 & 0.575 & 0.562 \\
\hline & Sig. (2-tailed) & 0.073 & 0.126 & & 0.257 & 0.144 & 0.005 & 0.007 \\
\hline & $\mathrm{N}$ & 22 & 22 & 22 & 22 & 22 & 22 & 22 \\
\hline \multirow{3}{*}{ Credit } & $\begin{array}{l}\text { Pearson } \\
\text { correlation }\end{array}$ & 0.952 & 0.972 & -0.253 & 1 & 0.944 & -0.058 & -0.574 \\
\hline & Sig. (2-tailed) & 0.000 & 0.000 & 0.257 & & 0.000 & 0.796 & 0.005 \\
\hline & $\mathrm{N}$ & 22 & 22 & 22 & 22 & 22 & 22 & 22 \\
\hline \multirow{3}{*}{$\begin{array}{l}\text { Total assess } \\
\text { deposit (Rs. } \\
\text { Cr) }\end{array}$} & $\begin{array}{l}\text { Pearson } \\
\text { correlation }\end{array}$ & 0.993 & 0.991 & -0.322 & 0.944 & 1 & 0.067 & -0.441 \\
\hline & Sig. (2-tailed) & 0.000 & 0.000 & 0.144 & 0.000 & & 0.767 & 0.040 \\
\hline & $\mathrm{N}$ & 22 & 22 & 22 & 22 & 22 & 22 & 22 \\
\hline \multirow{3}{*}{$\begin{array}{l}\text { CPI annual } \\
\text { average } \\
\text { variation (IW) }\end{array}$} & $\begin{array}{l}\text { Pearson } \\
\text { correlation }\end{array}$ & -0.017 & -0.006 & 0.575 & -0.058 & 0.067 & 1 & 0.588 \\
\hline & Sig. (2-tailed) & 0.939 & 0.977 & 0.005 & 0.796 & 0.767 & & 0.004 \\
\hline & $\mathrm{N}$ & 22 & 22 & 22 & 22 & 22 & 22 & 22 \\
\hline \multirow{3}{*}{$\begin{array}{l}\text { Bank deposit } \\
\text { rates (above } \\
\text { five yrs) }\end{array}$} & $\begin{array}{l}\text { Pearson } \\
\text { correlation }\end{array}$ & -0.479 & -0.485 & 0.562 & -0.574 & -0.441 & 0.588 & 1 \\
\hline & Sig. (2-tailed) & 0.024 & 0.022 & 0.007 & 0.005 & 0.040 & 0.004 & \\
\hline & $\mathrm{N}$ & 22 & 22 & 22 & 22 & 22 & 22 & 22 \\
\hline
\end{tabular}

